Case report

\title{
Unfavorbale Effects of Low-Carbonhydrate Diet In a Pediatric Patient With Type 1 Diabetes Mellitus Low-carbohydrate Diet in Type 1 Diabetes Mellitus
}

\section{Güleryüz et al. Ketogenic Diet in Type 1 Diabetes Mellitus}

Ceren Güleryüz ${ }^{1}$, Ece Ekerr ${ }^{1}$, Gülin Karacan Küçükali², Merve Şakar², Fatma Nur Genç²,Nursel Muratoğlu Şahin², Selin Elmaoğullar1 ${ }^{2}$, Semra Çetinkaya ${ }^{2}$, Şenay Savaş Erdeve ${ }^{2}$

${ }^{1}$ Dr. Sami Ulus Obstetrics and Gynecology, Children Health and Disease Training and Research Hospital, Department of Pediatrics, Ankara, Turkey

${ }^{2}$ Dr. Sami Ulus Obstetrics and Gynecology, Children Health and Disease Training and Research Hospital, Department of Pediatric Endocrinology, Ankara, Turkey

What is already known on this topic?

Ketogenic diet is used in adults who are obese or have type 2 diabetes. Its use in children is only limited to resistant epilepsy.

What this study adds?

Ketogenic diet is not recommended for glycemic control in children with T1DM, as it causes growth retardation, increased blood lipid levels, and risk of cardiovascular disease. Nutritional therapy for children and adolescents with T1DM should be based on universally accepted clinical guidelines.

\begin{abstract}
A balanced and healthy diet is very important in type 1 diabetes mellitus in childhood. In addition to regulating blood glucose with diet, it should be aimed to support adequate growth. Low-carbohydrate diet aims to provide daily energy from fats and is originally used for childhood epilepsy. We will present a patient with type diabetes mellitus who has the unfavorable effects of the low-carbohydrate diet.
\end{abstract}

Keywords: low-carbohydrate diet, type 1 diabetes mellitus, nutrition therapy, childhood

Gülin KARACAN KÜÇÜKALİ MD, University of Health Sciences Turkey, Dr. Sami Ulus Maternity, Child Health and Diseases Training and Research Hospital, Pediatric Endocrinology Clinic, Altındag /Ankara, 06020, Turkey gulinkucukali@gmail.com

$+905337648426$

05.11 .2021

14.12 .2021

0000-0001-7506-1711

Published: 11.01 .2022

\section{Introduction}

Nutrition therapy is one of the basic parts of type 1 diabetes mellitus (DM) management and should include macro and micronutrients that are based on universally accepted clinical guidelines. Also nutrition therapy should support the normal growth and development of children with the most appropriate metabolic control, and are suitable for healthy eating principles and nutritional habits of the person $(1,2)$. In the guidelines of the International Pediatric and Adolescent Diabetes Association (ISPAD), energy, it has been suggested that $45-55 \%$ be met from carbohydrates, $30-35 \%$ from fats $(<10 \%$ saturated fat + trans fatty acids), $15-20 \%$ from proteins (1).

The ketogenic diet $(\mathrm{KD})$ is a low-carbohydrate, protein-limited and high-fat diet that aims to provide daily energy from fats. Low-carb diets have recently been popularized on social media, by showing healthy on various platforms. Here, we present the clinical and laboratory findings of a patient who has been on a low-carbohydrate (low-carb) diet for two years after the diagnosis of Type 1 DM and the negative effects of this nutrition model in childhood will be discussed.

Case

A $6^{5 / 12}$ year-old female patient applied to our clinic because of being overweight. She was overweight after the age of three. She was born $2950 \mathrm{~g}$ at term. It was learned that the patient had no features in her prenatal and natal history. Also, her mother had Hashimoto's thyroiditis, father had multiple sclerosis, and 25-year-old sister had T1DM (who had been using insulin therapy for 18 years). Her height was $121 \mathrm{~cm}(0.49 \mathrm{sds})$, body weight (BW) was $31 \mathrm{~kg}(1.78 \mathrm{sds})$ and body mass index (BMI) was $21.17 \mathrm{~kg} / \mathrm{m}^{2}(1.87 \mathrm{sds})$, blood pressure was $120 / 70 \mathrm{mmHg}$, thyroid gland was non-palpable, pubertal stage was Tanner stage 1. In the laboratory examinations, glucose $90 \mathrm{mg} / \mathrm{dl}$, SGOT $34 \mathrm{U} / \mathrm{L}(<47)$, SGPT $24 \mathrm{U} / \mathrm{L}(0-39)$, cholesterol $217 \mathrm{mg} / \mathrm{dl}$ (96-211), LDL cholesterol $140 \mathrm{mg} / \mathrm{dl}$ (38-140), HDL cholesterol $57 \mathrm{mg} / \mathrm{dl}$ (>35), triglyceride $102 \mathrm{mg} / \mathrm{dl}$ (35-110), TSH 3.67 $\mu \mathrm{IU} / \mathrm{mL}(0.6-5.5)$, fT4 $1.26 \mathrm{ng} / \mathrm{dl}(0,8-1.9)$ were found. No fatty liver was detected in the abdominal ultrasonography (USG) The patient, who was overweight, was followed-up by making recommendations for a healthy diet with appropriate calories for her age and exercise. 
In the first year of her follow-up, when she was $7^{4 / 12}$ years old, while she applied with complaints of increased appetit and not gaining weight. Her height was $127 \mathrm{~cm}(0.74 \mathrm{sds})$, BW was $34 \mathrm{~kg}(1.98 \mathrm{sds})$ and BMI was $21.08 \mathrm{~kg} / \mathrm{m}^{2}(1.94 \mathrm{sds})$, blood pressure was $110 / 70 \mathrm{mmHg}$, pubertal stage was Tanner stage 1 and other system examinations were normal. Her blood sugar was detected $280 \mathrm{mg} / \mathrm{dl}$, HbA1c $7.8 \%$, c-peptide $0.925 \mathrm{ng} / \mathrm{ml}(1.1-4.4)$. The patient with positive diabetes autoantibodies (islet antibody $67.05 \mathrm{U} / \mathrm{ml}(<1)$, anti-GAD $41.45 \mathrm{U} / \mathrm{mL}(<1)$ ) was diagnosed with T1DM and intensive insulin regimen $(1$ $\mathrm{U} / \mathrm{kg} /$ day; $60 \%$ insulin lispro, $40 \%$ insulin glargin) was started. We recommended a diabetic diet to her [1711 kcal, $53 \%$ carbohydrates, $19 \%$ protein, $28 \%$ fat (5.8\% saturated fatty acids, $3.5 \%$ polyunsaturated fatty acids, $16.4 \%$ monounsaturated fatty acids)]. Diabetes education was given to the family and the patient.and she was discharged. The patient, who continued her follow-ups in the private endocrinology clinic for a while, was found to have TSH 27.4 $\mu \mathrm{IU} / \mathrm{mL}(0.6-5.5)$ and fT4 $1.42 \mathrm{ng} / \mathrm{dl}$ (0.8-1.9) during this period and Na-L thyroxin (LT4) treatment was started for hashimato thyroiditis. Then she left the pediatric endocrinology clinic and started to be followed in a private clinic. In this private clinic, the patient was given a low-carb diet list [1342 kcal, $23 \%$ carbohydrates, $23 \%$ protein, $54 \%$ fat $(15.8 \%$ saturated fatty acids, $11.8 \%$ polyunsaturated fatty acids, $22.8 \%$ monounsaturated fatty acids)]. She was fed with low-carb diet for two years, and the LT4 treatment was discontinued.

After two years on a low-carb diet, our patient applied to our department when she was $9^{3 / 12}$ years, because her blood sugar was high while she was fed low-carb diet. At that time, height was $131.7 \mathrm{~cm}(-0.35 \mathrm{sds}), \mathrm{BW}$ was $26.35 \mathrm{~kg}(-0.71 \mathrm{sds})$, BMI was $15.19 \mathrm{~kg} / \mathrm{m}^{2}(-0.69 \mathrm{sds})$, goiter stage $1 \mathrm{~b}$, puberty Tanner stage 1 and other system examinations were normal. The growth rate during feeding with KD was $4.7 \mathrm{~cm} / 2$ years. The patient's complete blood count, serum electrolytes, and kidney function tests were normal and SGOT $111 \mathrm{U} / \mathrm{L}(<47)$, SGPT $168 \mathrm{U} / \mathrm{L}(0-39)$, cholesterol $1029 \mathrm{mg} / \mathrm{dl}$, LDL cholesterol $826 \mathrm{mg} / \mathrm{dl}$, HDL cholesterol $136.2 \mathrm{mg} / \mathrm{dl}$, triglyceride $334 \mathrm{mg} / \mathrm{dl}$, TSH $10.275 \mu \mathrm{IU} / \mathrm{ml}$, fT4 $1.18 \mathrm{ng} / \mathrm{dl}, \mathrm{HbA} / \mathrm{c} 7.78 \%$, c-peptide 0.41 $\mathrm{ng} / \mathrm{mL}$ were found. Stage 1 hepatosteatosis was detected in abdominal USG. Carotid color doppler USG and echocardiographic examinations of the patient who had high lipid levels were normal. No diabetic retinopathy was detected in the eye examination. The patient was started on intensive insulin regimen (multiple daily injection treatment, $1 \mathrm{U} / \mathrm{kg} / \mathrm{day}$; $60 \%$ insulin lispro and $40 \%$ insulin glargine treatment) and LT4 therapy. Her nutrition therapy was revised again [1908 kcal, $56 \%$ carbohydrates, $18 \%$ protein, $26 \%$ fat $(5.5 \%$ saturated fatty acids, $3.4 \%$ polyunsaturated fatty acids, $15 \%$ monounsaturated fatty acids)]. Atorvastatin treatment was started with the recommendation of the metabolism department until the blood lipid parameters decreased to acceptable levels, and ursodeoxycholic acid and vitamin E treatments were started with the recommendation of the gastroenterology department for elevated transaminases. The structured diabetes and diet education was given to the patient and her family again. The mother could hardly be persuaded to adhere to the healthy eating plan. In the follow-up, it was observed that there was an improyement in growth rate $(5.04 \mathrm{~cm} /$ years $)$, liver function tests returned to normal, and cholesterol levels decreased. The follow-up datas of the patient is given in Table 1. Dietary contents at diagnosis and follow-up are given in Table 2.

\section{Discussion}

Low-carb diets, which have recently become one of the trendy diets, have been popularized by showing healthy in social media, individual internet blogs, television and nutrition magazines.

If there is more than 55\% carbohydrate intake of daily energy, it is called high carbohydrate diet, approximately $45 \%$ intake is average carbohydrate, less than $26 \%$ intake is low carbohydrate, and if there is less than $10 \%$ intake, it is called very low carbohydrate diet (6). KD is a low-carbohydrate, protein-limited, high-fat, long-chain triglyceride-rich diet that aims to meet daily energy from fats. Protein intake is kept at the lower limit of daily requirement and carbohydrate intake is severely limited. The use of KD in pediatric population is limited to the epilepsy treatment (3). While the side effects of the ketogenic diet in the acute period are vomiting and fatigue, in the chronic period, side effects such as stagnation in growth and development, impaired lipid profile, vitamin-mineral deficiencies, pancreatitis, kidney stones, arrhythmia, cardiomyopathy, and osteopenia have been reported $(4,7)$.

The use of KD has come to the fore in individuals with diabetes, with the thought that it reduces both glycemic fluctuations and insulin need with less carbohydrates, but studies investigating its place in T1DM treatment are mostly studies with a small sample, conducted in the adult age group $(4,5)$. Childhood diabetes differs from adult diabetes in that it has longer sleep duration, frequent infections, unpredictable physical activity and eating patterns, non-adherence to treatment in adolescence, concerns about appearance, variable metabolic status, and insulin requirement (1). Therefore, it is unavoidable that there will be differences in treatment management.

Since nutrition with KD cannot provide enough energy in growing children, the most striking feature is the slowdown in growth rate. Our case also lengthened $4.7 \mathrm{~cm}$ in total during the two years that she applied KD, which was insufficient for her age. After a healthy diet and multi-dose insulin therapy, the annual growth rate returned to normal. There is a misconception that less carbohydrate consumption and therefore reduced insulin requirement are better in KD nutrition, but insulin is directly and indirectly effective in cell growth and proliferation. Insulin acts by binding directly to the IGF-1 receptor, indirectly increasing the hepatic production of IGF-1, and is in a synergistic relationship with growth hormone and other growth stimulating factors $(2,8)$. As in $\mathrm{KD}$, high-fat diets have also been shown to blunt pituitary growth hormone secretion. Growth arrest has been reported in the literature in patients with T1DM fed low carbohydrate $(2,7)$. It has also been shown that children with T1DM who receive intensive insulin therapy and are fed low carbohydrate and high fat have worse glycemic control and higher HbA1c values (8). There are also studies showing that feeding with KD increases the risk of hypoglycemia and impairs the effectiveness of glucagon used in the treatment of hypoglycemia (9). In nutritional studies, it has been observed that as the amount of carbohydrates in the daily diet decreases, children tend to consume lower quality foods (10).

Another negative aspect of KD is that it increases blood lipids. Since the blood lipid results in our patient were above the values seen in familial homozygous hypercholesterolemia, which is the most severe form of hypercholesterolemia, and the lipid profile measured at the age of $6^{5 / 12}$ years was close to normal, increased lipid levels were considered as a serious complication of KD. Cases of dyslipidemia after feeding with KD have been reported previously $(2,7)$. In a series in which six children with T1DM who followed a low-carbohydrate diet were reported, there was a case with dyslipidemia (2). The 
development of dyslipidemia is associated with excessive consumption of saturated fats instead of carbohydrates reduced in the diet, and worryingly increases the risk of cardiovascular disease (11).

Consumption of more than one type of food group and making restrictions in nutrition in childhood also bring psychological comorbidities. It causes social isolation and related psychosocial burden for children. In addition, this restricted eating pattern may lead to eating disorders in the future (2).

As a result; in T1DM, the nutrition plan should include sufficient energy and micro and macronutrients to ensure the growth of the child. Nutritional therapy with KD is not recommended for glycemic control in children with T1DM, as it causes growth retardation, increased blood lipid levels, and increased risk of cardiovascular disease. Nutritional therapy for children and adolescents with T1DM should be based on universally accepted clinical guidelines.

(Written informed consent was obtained from the parents of the patient.)

\section{References}

1. Smart CE, Annan F, Higgins LA, Jelleryd E, Lopez M, Acerini CL. ISPAD Clinical Practice Consensus Guideline 2018: Nutritional management in children and adolescents with diabetes. Pediatr Diabetes 2018;19:136-54.

2. de Bock M, Lobley K, Anderson D, Davis E, Donaghue K, Pappas M, et al. Endocrine and metabolic con due to restrictive carbohydrate diets in children with type 1 diabetes: An illustrative case series. Pediatr Diabetes 2018;19(1):129-37.

3. Sharma S, Jain P. The ketogenic diet and other dietary treatments for refractory epilepsy in children. Ann Indian Acad Neurol 2014;17(3):253.

4. Dhamija R, Eckert S, Wirrell E. Ketogenic diet. Can J Neurol 2013;40(2):158-67.

5. Bolla AM, Caretto A, Laurenzi A, Scavini M, Piemonti L. Low-carb and ketogenic diets in type 1 and type 2

diabetes. Nutrients 2019;11(5):962.

6. Seckold R, Fisher E, de Bock M, King B, Smart C. The ups and downs of low-carbohydrate diets in the management of Type 1 diabetes: a review of clinical outcomes. Diabet Med 2019:36(3):326-34.

7. Kwiterovich Jr PO, Vining EP, Pyzik P, Skolasky Jr R, Freeman JM. Effect of a high-fat ketogenic diet on plasma levels of lipids, lipoproteins, and apolipoproteins in children. JAMA 2003;290(7):912-20.

8. Lennerz BS, Barton A, Bernstein RK, Dikeman RD, Diulus C, Hallberg S, et al. Management of type 1 diabetes with a very low-carbohydrate diet. Pediatrics. 2018;141(6).

9. Katz ML, Mehta S, Nansel T, Quinn H, Lipsky LM, Laffel LM. Associations of nutrient intake with glycemic control in youth with type 1 diabetes: differences by insulin regimen. Diabetes Technol Ther 2014;16(8):512-8.

10. Ranjan A, Schmidt S, Damm-Frydenberg C, Steineck I, Clausen TR, Holst J, et al. Low-carbohydrate diet impairs the effect of glucagon in the treatment of insulin-induced mild hypoglycemia: a randomized crossover study. Diabetes Care 2017;40(1):132-5.

11. Margeirsdottir H, Larsen J, Brunborg C, Øverby N, Dahl-Jørgensen K. High prevalence of cardiovascular risk factors in children and adolescents with type 1 diabetes: a population-based study. Diabetologia 2008;51(4):554-61.

12. Øverby N, Flaaten V, Veierød M, Bergstad I, Margeirsdottir H, Dahl-Jørgensen K, et al. Children and adolescents with type 1 diabetes eat a more atherosclerosis-prone diet than healthy control subjects. Diabetologia 2007;50(2):307-16.

Table 1. Clinical and laboratory findings of our patient with type 1 diabetes who applied low-carb diet

\begin{tabular}{|c|c|c|c|c|c|}
\hline & First application & $\begin{array}{l}\text { At the diagnosis of } \\
\text { diabetes }\end{array}$ & $\begin{array}{l}\text { First application } \\
\text { after low-carb diet }\end{array}$ & $\begin{array}{l}\text { 3rd month control } \\
\text { after a healthy diet } \\
\text { plan and intensive } \\
\text { insulin therapy }\end{array}$ & $\begin{array}{l}\text { One year after a healthy } \\
\text { diet and intensive insulin } \\
\text { therapy }\end{array}$ \\
\hline Age (years) & $6^{5 / 12}$ & $7^{4 / 12}$ & $9^{3 / 12}$ & $9^{6 / 12}$ & $10^{5 / 12}$ \\
\hline Height $(\mathrm{cm}) / \mathrm{sds}$ & $121(0,49)$ & $127(0,74)$ & $131,7(-0,35)$ & $132,5(0,45)$ & $136,7 \mathrm{~cm}(-0,65)$ \\
\hline Weight (kg)/ sds & $31(1,78)$ & $34(1,98)$ & $26,35(-0,7)$ & $28,25(-0,48)$ & $32,85(-0,31)$ \\
\hline $\begin{array}{l}\text { Body mas } \\
\left(\mathrm{kg} / \mathrm{m}^{2}\right) / \mathrm{sc}\end{array}$ & 21 & $\begin{array}{l}21,08 \\
(1,94)\end{array}$ & $15,19(-0,69)$ & $16,09(0,31)$ & $17,5(0,04)$ \\
\hline Puberty & 1 & 1 & 1 & 1 & 2 \\
\hline Growth rate & - & $6 \mathrm{~cm} /$ year & $4.7 \mathrm{~cm} / 2$ year & $0.8 \mathrm{~cm} / 3$ month & $5.04 \mathrm{~cm} /$ year \\
\hline HbA1c (\%) & - & 7.1 & 7.78 & 6.19 & 7.8 \\
\hline C-peptid (ng/ml) & - & 1.1 & 0.41 & & \\
\hline $\begin{array}{l}\text { Cholesterol } \\
(\mathrm{mg} / \mathrm{dl})\end{array}$ & 217 & 203 & 1029 & 348.0 & 351 \\
\hline
\end{tabular}




\begin{tabular}{|c|c|c|c|c|c|}
\hline $\begin{array}{l}\text { LDL cholesterol } \\
\text { (mg/dl) }\end{array}$ & 140 & 125 & 826 & 249 & 255 \\
\hline $\begin{array}{l}\text { HDL cholesterol } \\
(\mathrm{mg} / \mathrm{dl})\end{array}$ & 57 & 53 & 136.2 & 88.9 & 80,5 \\
\hline $\begin{array}{l}\text { Triglyceride } \\
\text { (mg/dl) }\end{array}$ & 102 & 125 & 334 & 50 & 80 \\
\hline SGOT (U/L) & 34 & 33 & 111 & 52 & 28 \\
\hline SGPT (U/L) & 24 & 22 & 168 & 53 & 17 \\
\hline Abdominal USG & Normal & - & $\begin{array}{l}\text { Stage 1 } \\
\text { hepatosteatosis }\end{array}$ & - & \\
\hline TSH $(\mu I U / m L)$ & 3.675 & 2.876 & 10.275 & 1.091 & \\
\hline sT4 (ng/dl) & 1.26 & 1.07 & 1.18 & 1.59 & \\
\hline $\begin{array}{l}\text { Anti TPO } \\
\text { (IU/mL) }\end{array}$ & 287.6 & 538.1 & 1300 & - & \\
\hline Anti Tg (IU/mL) & 29.5 & 223.2 & 289.4 & & \\
\hline
\end{tabular}

Table-2: Composition of the three dietary interventions

\begin{tabular}{|l|l|l|l|}
\hline & Reference diabetic diet & Carbohyrate-restricted diet & Reference diabetic diet \\
\hline Age (years) & $7^{4 / 12}$ & $9^{3}$ & $9^{6 / 12}$ \\
\hline $\begin{array}{l}\text { Total energy intake } \\
\text { (kcal) }\end{array}$ & 1711 & 1342 & 1908 \\
\hline Carbohydrates (g) & 222 & 75.9 & 260 \\
\hline Carbohydrates (\%) & 53 & 23 & 56 \\
\hline Fibre (g) & 41.4 & 12.8 & 46.1 \\
\hline Protein (g) & 77.0 & 75.1 & 83.2 \\
\hline Protein (\%) & 19 & 23 & 18 \\
\hline Fat (g) & 53.6 & 81.1 & 55.6 \\
\hline Fat (\%) & 28 & 54 & 26 \\
\hline SFA (g) & 11.2 & 23.6 & 11.7 \\
\hline SFA (\%) & 5.8 & 15.8 & 5.5 \\
\hline PUFA (g) & 6.7 & 17.7 & 7.3 \\
\hline PUFA (\%) & 3.5 & 11.8 & 3.4 \\
\hline MUFA (g) & 31.3 & 34.0 & 31.9 \\
\hline MUFA (\%) & 16.4 & 22.8 & 15.0 \\
\hline Cholesterol (mg) & 252.3 & 319.1 & 291.9 \\
\hline Trans fatty acids(g) & 0 & 0 & 0 \\
\hline & & & \\
\hline
\end{tabular}

* Abbreviations: SF A, saturated fatty acids; PUFA, polyunsaturated fatty acids; MUFA, monounsaturated fatty acids. 